\title{
Takeover Defenses in the Greek Economy
}

\author{
Isidora Tachmatzidi ${ }^{1}$
}

\begin{abstract}
:
Takeover defenses are crucial factors for the success of a takeover bid. The European Commission considers takeovers a significant factor for the economic integration strategy of the EU and the Takeover Directive was issued in 2004 to regulate takeover bids.
\end{abstract}

However, it is also important to consider the structural characteristics of the economy in which they operate. There is the concern that EU Member States have different market, legal and cultural structures.

The present paper gives a description of takeover defenses and their application in the Greek economy; a weak economy operating in a premature non-contestable market with concentrated ownership structure. It analyzes the role of takeover defenses in Greece that has implemented the EU Takeover Directive in its jurisdiction.

Subsequently, the legal framework is examined, followed by relevant case law and takeover activities related to market sectors that include banking, pharmaceutical, shipping, banking as well as privatizations.

The examination of takeover defenses in hostile takeovers in the Greek market aims to promote the understanding of the operation of takeover defenses in a weak economy and to offer further understanding on the way economic growth and market structure characteristics influence takeover defenses and vice-versa.

It, also, aims to provide feedback on future policy implementation in Greece and the European Union for the advancement of harmonization.

Keywords: Takeover defenses, hostile takeovers, legal framework, economy structure, weak economy, market structure, banking industry, shipping industry, pharmaceutical industry, privatization.

\footnotetext{
${ }^{1}$ King's College London, Law of Laws Master(LLM),e-mail: itachmatzidi@hotmail.com
} 


\section{Introduction}

Member States within the European Union (EU) are subject to takeover transactions. In particular, in cases of hostile takeovers, the board of directors of the target company might employ certain legal strategies, called takeover defences. However, these defences may have different approaches in countries where their economies are in crisis, such as Greece. Therefore, when discussing the takeover defences that could be employed, it is crucial to consider also, the market structure of the country in which takeover defences are examined (Tachmatzidi, 2016). The present paper will focus on post-bid defences.

\section{Literature Review}

\subsection{Takeover defences overview}

A 'takeover bid' is a public offer made by a bidder to the shareholders of a target company in order "to acquire all or some of those securities...which...has as its objective the acquisition of control of the offeree company", according to Article 2(1)(a) Takeover Directive 2004, which was implemented in order to regulate takeovers within the European Union (Takeover Directive 2004).

Takeovers can be categorised in friendly or hostile (Gorzala, 2010). Friendly takeovers take place when the target board of directors approves the takeover offer made by the bidder. In contrast, hostile takeovers involve the bidder company making an unsolicited takeover bid to the target shareholders and attempting to acquire the target company without the approval of the target board. Consequently, the target board employs defences to obstruct the unwanted takeover. These defences can be employed either before the announcement of the takeover bid, i.e. pre-bid defences, or after the announcement of the bid or when the target board becomes aware that the bid is imminent, i.e. post-bid defences (Clerc, 2012).

\subsection{Frustrating and defensive actions}

There are two different views in relation to defences for hostile takeovers. One view is the supporters of the "board neutrality rule", which states that the target board of directors should not perform any action to obstruct a takeover bid without prior consent of the target shareholders (Article 9, Takeover Directive 2004). However, there are also, the advocates of the "non-neutrality rule", which support the target board employing actions to frustrate the offer.

According to the two different views of defences for takeovers, the board neutrality advocates and the non-neutrality supporters, post-bid takeover defences can be divided in two categories; frustrating and defensive actions (Kraakman et al., 2009). Frustrating acts are a type of defences taken by the target board of directors when it believes a takeover is imminent or when a takeover bid has already been made. The 
result of these defences is the obstruction or frustration of the takeover (Takeover Directive 2004). Certain examples of frustrating actions are "restructuring defences", "greenmail" and "litigation". Defensive actions, as opposed to frustrating actions, are defences that law allows the board of directors to employ them when it becomes aware that the bid is imminent or when there has already been made a takeover offer (Takeovers Panel, 2013). It is used as means to influence the targets' shareholders in relation to a takeover bid. Additionally, they do not deprive shareholder rights from the decision-making process, nor they material corrupt it.

It is important to mention that extensive requirements by company law, such as disclosure requirements, are particularly useful, as they offer more time to the board of directors to formulate strategies with defence actions that are not prohibited by law (Kraakman et al., 2009), as well as shareholders have a more complete view of the facts and advantages and disadvantages of takeovers in general (Stokka, 2013). Defensive actions include the issuing of "defence documents", "lobbying", the usage of "White Knight" or "White Squire" and the issuing of "profit forecasts".

\subsection{Advantages and disadvantages of takeover defences}

Takeover defences can have many advantages. Firstly, they can be beneficial, since they can be considered as negotiating tools that allow the target board to place pressure on the bidder to offer a higher premium for the shares, and in the meantime increasing the market value of the company. This is considered as the 'bargaining power hypothesis' (Ruling, 2012). If no defences are employed, the shareholders can only either take the premium offered or remain with the current market price for their shares. Negotiation can take place with the bidder to increase its offer, but this can also, result to an auction. Auctions as well increase bid premiums. If the target board discourages the shareholders to accept the first bid and in the meantime encourages other bidders to enter in a bidding contest for the target, this will result to both the initial bidder but also new bidders to offer a really high premium; increase of the value of the target company and of shareholder the wealth will most likely be accomplished. There have also, been cases (Ruling, 2012) which demonstrate that the use of defences, such as greenmail for instance, were able to increase the stock price by $7 \%$.

Furthermore, takeover defences can operate as a disciplinary tool for the target board of directors (Ruling, 2012). The possibility of a hostile bidder taking over the company provides the board with the incentive to manage the company in the most efficient way and to maximize shareholder wealth at the fullest. Takeovers defences can also, benefit the markets in general, because they produce information in relation to the target company, which in some cases its shares might have been undervalued due to lack of accurate information (Ruling, 2012). Hence, if the target board is able to fight a hostile bidder, its share price might increase as it shows strength in the marketplace. Moreover, the information created by defences can also, result to a 
more open and efficient operation of the market; this is in particular, beneficial for premature economies such as the Greek one.

In contrast, takeover defences can also, result to disadvantages. An argument that can be used against the employment of takeover defences is that the target shareholders might lose the benefit that could have been obtained had not defences been employed. The benefit stems from the large premium offered in a takeover for the shareholders shares from a hostile bidder (Ruling, 2012). Usually the price offered is higher from the current market price in order to influence the shareholders to proceed with accepting the takeover bid. The shareholders can also, benefit from the increase in the share price even before the official bid announcement and its steady increase until the announcement. If however, the target board employ defences, the shareholders will not have the opportunity to sell their shares at a higher price, resulting to loss of profits. Another disadvantage of takeover defences is the board's reduced motivation for shareholder wealth maximization or increase of the company's profits, since it will be able to employ takeover defences and not be threatened by dismissal (Ruling, 2012).

The aforementioned functioning of the takeover defences in market activities attracted the attention of the European Community whose one of the primary purposes is the total elimination of barriers of trade. Although Article 56 of the EC Treaty states that 'all restrictions on the movement of capital between Member States ... shall be prohibited' (Treaty establishing the European Community), Article 12 of the Takeover Directive makes the board neutrality rule optional and not mandatory for all Member States, which can be considered as an obstacle to free capital movement (Mukwiri, 2008).

\section{Greek market characteristics}

The first seed for the market for corporate control was implanted in the beginning of 1990's due to the economic integration of the European Union (Fragakis, 2010). The Greek companies, the majority of which were family owned started to merge in order to become more powerful in the marketplace. However, this growth came to a standstill when the economic crisis hit Greece in 2009. This brought instability in the economic, political and social environment.

Consequently, two market characteristics that hinder the development of a market for corporate control and consequently, hinder the development a takeover market, of Greece remained (Drakopoulos, 2014). Firstly, most listed companies in Greece continue to be either family or state owned, which means that the majority of the company is controlled either by a family or by the state, sometimes the stake can even surpass the $75 \%$ of the whole capital. Secondly, the Greek market is very concentrated so even those companies that are not family or state owned, they are not able to operate properly and competitively. Therefore, the market in Greece can be characterised as premature, since there is no economic growth, the companies are 
mostly family or state owned and investors are not attracted to invest in such a market (Fragakis, 2010). Other characteristics that hinder market development in Greece are cultural factors, but they will not be analyzed in the present dissertation.

Furthermore, Greece does not have a contestable market, which is a major determinant to examine if there is a market for corporate control. A market which is contestable has low barriers to entry or exit for companies and there are low sunk costs (Arnold, 2010). Such a market is considered highly competitive, due to the constant threat that another company might enter the market place therefore the already existing firms need to be productive and competitive in order to remain in the market. However, efforts are being made to create a stable economic market through bailout mechanisms and schemes since the economic crisis hit Greece.

\subsection{Greek takeover regulation}

The EU Takeover Directive 2004 has been implemented under Greek law with Law 3461/2006, known as the 'Takeover Bid Law' (Karatzas, 2012). The main regulatory bodies in Greece for takeovers are the Hellenic Capital Market Committee ('HCMC'), the Hellenic Competition Committee ('HCC') and the Civil Courts in relation to resolution of disputes.

'Board neutrality' and 'reciprocity' are principles that can be found in the Greek Takeover Bid law (Staikouras, 2008). The 'board neutrality' rule prevents the board of directors from adopting takeover defences that could frustrate an imminent takeover without the prior authorisation of the shareholders in the general meeting (Drakopoulos, 2014). This rule is found under Article 14(1) of Law 3461/2006. The only exception is when the board is seeking alternative bids or when using defensive measures that do not affect shareholder rights or decision-making processes. There are also, time limits in relation to the prevention of frustrating actions by the target board (Skouzos, 2016). They are imposed from the day the takeover bid is announced or the day that the target company becomes aware that the bid is imminent until the publication of whether the takeover bid has been successful or not.

The 'reciprocity' principle on the other hand, under Article 14(4) states that the target company has the choice of not applying the 'board neutrality' rule if the bidder is a company that itself does not apply Article 14(1) or if it is under the direct or indirect control, of another company that does not apply Article 14(1). However, such a decision has to precede the announcement of the takeover bid by eighteen months and the relevant authorities and the Capital Market Commission need to be informed (Act 3461/2006, Article 14(4)).

Furthermore, the board of the target company should issue a report, which is a public document, usually on the $24^{\text {th }}$ day after the public announcement of the takeover bid (Gramatidis and Koromantzos, 2015). It contains its decision in relation to the 
takeover offer and provides reasons alongside it. In particular, it should include all the agreements made between the hostile bidder and the board (Kyriakopoulos, 2008). It should also, include the reasons of the board for supporting or not the takeover offer, as well as assessments of the result the bid would have for the company and its employees, as well as the managerial plan the bidder will use for the target company.

\subsection{Takeover defences in the Greek market}

Since the Greek market is still considered premature, it will be demonstrated that many takeovers have taken place recently, leading, potentially, towards the formation of a market for corporate control. The main industries that takeover transactions have occurred in the recent years, and that will be analyzed below, are the banking, shipping and pharmaceutical ones, as well as there have been many privatisations of public companies. In 2015, the mergers and acquisitions in the banking industry reached $36,8 \%$, the pharmaceuticals were $35,5 \%$ and the shipping industry representing $7,8 \%$ ( $\mathrm{PwC}, 2016)$. The privatisations generated $€ 268 \mathrm{~m}$ and in 2016 it is estimated that they will reach $€ 5,4 \mathrm{bn}$, which demonstrates growth of the market.

The frustrating defences stated earlier, such as restructuring defences, greenmail and litigation, are not permitted to be taken by the target board according to Article 14(1) of law 3461/2006, since they result in the deprivation of the target shareholders rights to decide on the merits of the takeover offer and they most likely corrupt the decision-making process. The only instances that these defences are allowed in Greece are two (Tsibris and Koumettis, 2014). Firstly, if the target shareholders or the panel has given its approval prior to the employment of the frustrating actions, they are considered frustrating only for the hostile bidder and not for the target shareholders since they have approved them. Secondly, if the target fallen under Article 14(4) that has been previously analyzed. In Greece however, frustrating measures are not used often, as opposed to defensive measures which are more common (Gramatidis and Koromantzos, 2015). Only litigation might be used in some transactions cases while at the stage of suggested acquisition.

Defensive measures on the other hand, are permitted by the law to be applied (Tsibris and Koumettis, 2014). The board therefore, is allowed to issue defence documents and publish profit forecasts as actions to present to the target shareholders arguments against the takeover offer. Lobbying especially, is really often and extensive in Greece. Nevertheless, the target board is required by law to provide its opinion in relation to the takeover bid and can also, place on the agenda of discussion at the shareholder meeting proposals for defensive actions. The target shareholders, during the general meeting of shareholders, will make a decision on whether to proceed or not with the measures proposed by the board, according to Article 14(2). Furthermore, according to Article 14(1), the target board is permitted 
to seek for alternative bidders, 'White Knight' and 'White Squire' defences, to takeover the company without prior shareholder approval.

However, not all frustrating and defensive actions can be translated into the Greek economy. Thus, the industries which mostly encountered takeovers and transactions in general, will be analysed and possible legal defences based on Greek Law, besides the frustrating and defensive measures considered above, will be examined.

\subsection{Banking industry}

The Greek banking sector has experienced huge developments in recent years as regards takeovers (PWC, 2016). In 2013, the Greek Public participated in the recapitalization of the four main Greek banks by offering $€ 25 \mathrm{bn}$ in exchange of $80 \%$ of their shares (Papageorgiou, 2015). After the second recapitalization in 2013, in which only private investors participated, €8,3bn was offered and the Greek Public share was reduced to $56,2 \%$, which after further recapitalization reached $17 \%$.

One of the transactions involved is the takeover of Millennium Bank and subsidiaries or branches of Cypriot banks from Piraeus Bank for $€ 924 \mathrm{~m}$. Another transaction was the sale of Eurobank Properties and "National Pangaia" for $€ 817 \mathrm{~m}$. An interesting case is Piraeus Bank, which has engaged in major takeovers lately (Staurou, 2014). It was founded as a private bank that then went under public control, only to be privatised again, resulting to its successful growth. Its recent takeovers include major parts of Agricultural Bank of Greece and General Bank, as well as banking operations of Cyprus Bank, Cyprus Popular Bank and Hellenic Bank. Piraeus Bank also, took over Millennium Bank of Greece. In 2014, it completed successfully $€ 1.75$ bn capital increase with new common shares which were made available to foreign, as well as Greek investors. This demonstrates the growing trust of foreign and domestic investors in the future of the Bank. Nowadays, the Bank has fully incorporated the banks it took over in recent years.

\subsection{Pharmaceutical industry}

The pharmaceutical industry in Greece is another area in which takeovers have occurred. In 2011, Watson Pharmaceuticals Inc WPI.N took over Greek Specifar Pharmaceuticals SA for $€ 400 \mathrm{~m}$ (Anastasiadis, 2013) and instantly, Watson shares rose $1.5 \%$ (Krauskopf, 2011). This takeover was positive for the Greek market, because Watson is a company involved with generic medicines which is an underdeveloped market in Greece. Therefore, since generics are less expensive medicines than original ones, the reduction of the public hospitals' pharmaceutical expenditure resulted to a dynamic increase of business in the relevant market (Group of PRO.SY.FA.PE., 2011). Additionally, Watson promised to retain Specifar's employees, as well as to triple their number within the following five years (Group of PRO.SY.FA.PE., 2011). It has been suggested (Mandavelis, 2011) that this takeover has brought more credibility and trust to the Greek economy, which means 
that in the coming years even more investors could be attracted since the economy does not show a static position.

Another major takeover involved UK BC Partners Limited acquiring $80 \%$ of Greek Pharmathen for $€ 470 \mathrm{~m}$ in 2015 (PWC, 2016). Despite the economic crisis, Pharmathen was investing yearly $€ 20 \mathrm{~m}$ for pharmaceutical research and expansion (Kostis and Stathopoulos, 2015). Moreover, Pharmathen is mainly an exporting company (80\%), which means that the difficult economic situation of Greece will not hinder its growth. Pharmathen will be involved in the research and development of new products, will expand to new markets by using BC Partners international network and will be used as an export platform for other pharmaceutical companies. This strategic plan will grow even further the pharmaceutical market in Greece and will attract more investors, as well as job opportunities, resulting to unemployment reduction and GDP increase. Consequently, more takeovers will most likely take place.

\subsection{Shipping industry}

Takeovers in the area of shipping have been increasing recently with positive results for the Greek economy. In 2014 a takeover worth $€ 510 \mathrm{~m}$ occurred between two Greek companies; Star Bulk Carriers Corp took over from Excel Maritime Carriers Ltd 34 ships of dry bulk carriage (PWC 2015). Furthermore, Fortress Investment Group made a strategic deal with Attica Holdings SA for €75m (PWC 2015).

Fortress Group is based in the US, whereas Attica Holdings, a leading company in the East Mediterranean, which is a member of the Greek-based Marfin Investment Group. By this takeover, it is demonstrated that the shipping market in Greece continues to play a crucial position in the global economy despite the economic crisis and foreign investor groups still show trust to the Greek companies and economy; such trust will attract more investors, thus leading to economic growth.

Additionally, the takeover of US Nautilus Offshore Services Inc by Greek DryShips Inc. through its parent company Ocean Rig UDW Inc. in 2015 was a major deal. This demonstrates that not only foreign investors are interested in the Greek shipping industry, but Greek companies are expanding and taking over foreign companies as well.

\subsection{Potential takeover defences for banking, pharmaceutical and shipping industries}

It is interesting to consider a situation where, for instance, a bank or a pharmaceutical or a shipping company would be the target of a hostile bid, what takeover defence it would most likely use besides the ones considered above. The defences mentioned below can most likely be used for other industries, such as the food, retail, real estate and transportation industries, as well. 
A defence is divestitures, which are actions taken by the target board for selling specific business interests or investments of the target (Karamitri, 2010). This results to the increase of the targets' share price, which will make the hostile takeover less likely.

Furthermore, the Corporate Charter of the target company can be used by the board as a defence (Karamitri, 2010). The Charter is a legal document which states the incorporation of the target company and also, includes its governance and the corporate statutes of the country of incorporation of the company. In the Charter, the laws that govern a possible takeover can be found, which usually state that $2 / 3$ of shareholders need to decide positively for a takeover for it to occur. However, in the case of a hostile bid, it can be proposed for the Corporate Charter to be amended, according to Law 2190/1920, and require a higher majority of shareholders in order to proceed with the takeover.

Another possible defence is privatisation under Law 2000/91 (Karamitri, 2010). This defence involves a company which is public and becomes privately held by investors. As a result, the company is no longer trading in the market and the target shareholders are obliged to sell their shares. In order to do so, they must be paid a premium on the market price of the share. However, this process can be risky for a bidder interested to acquire the company, since the value created should be higher than the premium.

A law area in Greece from which the board of directors can benefit as a defence against a hostile takeover is the Labour law found in Law 1387/83, as amended by Law 2736/1999 and 2874/2000 and later signed by the President of the Greek Republic creating the Presidential Decree (PD) 178/2002. Firstly, according to Article 4 PD 178/2002, in a case of a successful takeover, the labour relationship is required to remain the same, as well as the rights and responsibilities of the employees. Moreover, if the hostile bidder is successful in the takeover, it must consider that according to the collective redundancies legislation only a specific amount of employees are allowed to be dismissed at the same time.

The aforementioned requirements combined with chapter 6 of Law 1264/1982 that states that the employer is not permitted to replace current employees because they are participating in a lawful strike, provides a defence for the target board. This is because the board of directors can use the afore-stated arguments in order to influence the target shareholders, as well as the hostile bidder; even though the takeover might be successful, it can lessen the value of the company resulting to losses. This can be done because firstly, the bidder will face a hostile workforce which will not be able to dismiss and place his own and secondly, the bidder will most likely face strikes from the company's workers which if lawful, cannot dismiss them. Consequently, the company shares will most likely drop and the company will lose value. Hence, the target board can use employment and labour laws as a defence 
in order to demonstrate that these laws can lessen the company value and place barriers in cases where takeovers were successful with negative consequences.

Additionally, Greek transactions have the possibility of facing hurdles due to the general market system and regulation in Greece that as a result, may lead to the hinder or the complete obstruction of the takeover bid. These can be considered as takeover defences and approvals and regulatory clearances (Kyriakopoulos, 2008). For instance, the HCMC needs to approve the takeover offer. This however, can lead to delays of the takeover process due to the extreme bureaucracy Greece faces as a market. Additionally, depending on the industry that the takeover occurs, different approvals are required, such as from the Ministry of Economy, Development and Tourism or the Bank of Greece.

\subsection{Privatisations in infrastructure: airports and shipping ports}

One of the major changes occurring in the Greek economy is the privatisation of the public sector. Although until recently companies in Greece where owned by the public sector, many companies have been sold or are in the process of being sold to foreign or domestic private investors. An example is the recent privatisation of 14 regional airports under the ownership of Fraport AG - Slentel for the price of $€ 1,2 b$ (PWC, 2016). It is estimated that through this privatisation the Greek tourism will be highly strengthened. It is also, approximated that there will be considerable investments made that will most likely reach $€ 330 \mathrm{~m}$ during the first four years and $€ 1,4 \mathrm{~b}$ during the next forty years.

Another example is the case of the old Greek airport, the 'Hellinikon', which used to belong to the Greek public sector but Global Investment Group-Lamda paid €915m to acquire its shares and create a multipurpose development. Lamda is a consortium of investors which operates internationally and includes Latsis Group from Greece, Fosun Group from China and Eagle Hills from Abu Dhabi.

However, the Greek Central Archaeological Council has stated that Hellinikon is now declared as an archaeological site, therefore if the public sector would want to hinder this private-led development, it could base its argument on the archaeological quality of the area. Article 2(c) of Law 3028/2002 - FEK A-153/28-6-2002 defines that archaeological site is considered, amongst others, a piece of land for which there is proof that they have archaeological monuments or that they were part of historical land until 1830. Hence, the Hellinikon falls within the definition since the Archaeological Council found evidence. According to Article 14(1), archaeological sites can be declared as protection zones, resulting to the prohibition of construction of new buildings and installations. Therefore, this is an argument that can be put forward in order to obstruct the process of the private development.

However, since the Hellinikon has already been sold to private investors, prohibition of such kind would lead to compensation payments either for temporary delay or 
permanent prevention in the use of land according to Article 19. Such compensation would be extremely high and thus, it is not a preferred route to hinder the Hellinikon project. However, this case provides an example of a possible defence that could be used in Greece to prevent a hostile takeover by employing the law of protection of archaeological sites or monuments. Therefore, in the infrastructure industry, a target company that wants to obstruct a hostile takeover can employ a defence stating that the area which is to be sold or built is considered an archaeological site or includes an archaeological monument according to Law 3028/2002 - FEK A-153/28-6-2002.

The privatisation of shipping ports in Greece is also, another example of the transformation of public infrastructures becoming private. In particular, an agreement was recently signed for the privatisation of Piraeus Port Authority SA and its sale of $51 \%$ of its investment capital to investors Cosco Group (Hong Kong) Limited for $€ 280.5 \mathrm{~m}$ (Bellos, 2016). Furthermore, during the next five years, Cosco Group is requested, according to the agreement made with the Greek Public to fulfil its investment obligations. In the meantime, it will pay $88 \mathrm{~m}$ for increasing its shares from $51 \%$ to $67 \%$. It is estimated from research studies done by National Bank of Greece that this privatisation will bring developments in the shipping industry and in the Greek economy in general for instance, through the development of the shipping ports, transportation investments and the creation of jobs. In particular, the studies showed that the Greek economy will be boosted with $€ 5.1 \mathrm{bn}$ from this development and 125.000 jobs will be created.

\section{Conclusions, proposals, recommendations}

Takeover defences are strategies used by the board of directors of the target company in order to obstruct an imminent hostile takeover. They can be categorised in frustrating and defensive actions. Frustrating defences involve actions that result to a substantial corruption of the decision-making process or to the deprivation of shareholders' right to decide on the takeover bid. They are permitted only when the target shareholders have given prior approval or when the defences frustrate only the bidder and not the target shareholders. Defensive actions involve acts which are allowed to be obtained by the target board in order to influence the shareholders with the purpose of obstructing the bid.

Greek takeover law provides the legal framework for the regulation of frustrating takeover defences. However, Greece has little experience in cases relating to takeover defences, due to its weak economic status. Defensive actions, as well as other actions, which stem from the Greek law and the target board of directors might use to obstruct a hostile takeover, are not heavily regulated. Consequently, although recently there has been a development of the Greek market, it could be argued that Greek laws allow a wider approach in the regulation of actions that could hinder a takeover. 
As the Greek economy will possibly move towards the development of a market for corporate control, it is suggested for future studies to collect data and monitor takeover defences occurring in different Greek industries. Moreover, further research could be conducted regarding policy implementation in order to examine what additional regulations could be implemented in Greece to create a more safeguarded and coherent framework of takeover defences. Finally, as the differences in the market structures may not allow similar approaches, it is suggested that further consideration is given to the provision of a harmonized framework across Europe in relation to takeover defences regulation.

\section{References:}

Anastasiadis, A. 2013. Valuation of a non-listed company: Case Study of a pharmaceutical takeover. University of Piraeus (in Greek).

Arnold, R.A. 2010. Microeconomics ( ${ }^{\text {th }}$ edn), South-Western Cengage Learning.

Bellos, H. 2016. Sale of Port of Piraeus to Cosco for 368,5m (in Greek)

http://www.kathimerini.gr/846460/article/oikonomia/epixeirhseis/pwlhsh-olp-sthncosco-enanti-3685-ekat

Clerc, C. 2012. A legal and economic assessment of European takeover regulation. Marccus Partners and Centre for European Policy Studies.

Directive 2004/25/EC of the European Parliament and of the Council on Takeover Bids. European Takeover Directive 2004.

Drakopoulos Law Firm, 2014. Mergers and Acquisitions Report. Greece (2014 IFLR) Section 4.4 (in Greek).

Fragakis, E. 2010. Mergers and Acquisitions in Greece during the last decade. TEI Crete (in Greek).

Gorzala, J. 2010. The Art of Hostile Takeover Defences ( $1^{\text {st }}$ edn). IGEL Verlag.

Gramatidis, A., Koromantzos, A. 2015. Greece - Law \& Practice. Bahas, Gramatidis \& Partners.

Greek Law 3461/2006. 2006. Transposition of the Directive 2004/25/EC on Takeover Bids to the National Legislation (in Greek).

Greek Law 3028/2002. 2002. On the Protection of Ancient and Cultural Heritag (in Greek).

Greek Law 1387/83, as amended by Law 2736/1999 and 2874/2000, later creating Presidential Decree (PD) 178/2002. 2002. On the Protection of Rights of Employees in Case of Merger and Acquisition Transfer (in Greek).

Greek Law 1264/1982. 1982. On Democratisation of the Trade-Union Movement and Enshrinement of the Trade-Union Freedoms of Workers (in Greek).

Greek Law 2190/1920. 1920. On Limited Companies (in Greek).

Group PRO.SY.FA.PE 2016. The deal of Watson-Specifar is valuable for the Greek economy, http://www.prosyfape.gr/farmakeftikesexelixeis/newsid880/50 (in Greek).

Karamitri, E. 2010. Mergers and Acquisitions in the Banking Sector. University of Macedonia, (in Greek).

Karatzas \& Partners Law Firm. 2012. Mandatory and Voluntary Takeover Bids.

Kotsis, V., Stathopoulos, N. 2015. There are more Pharmathen in Greece http://www.tovima.gr/finance/article/?aid=710997 (in Greek).

Kraakman, R., Armour, J., Davies, P., Enriques, L., Hansmann, H., Hertig, G., Hopt, K., 
Kanda, H., Rock, E. 2009. The Anatomy of Corporate Law ( $2^{\text {nd }}$ edn). Oxford University Press, UK.

Krauskopf, L. 2011. Watson Pharma buys Greece's Specifar for \$562 million. Reuters, NY, http://www.reuters.com/article/us-watson-idUSTRE74O59R20110525

Kyriakopoulos, T. 2008. Greece, ICLG 2008.

Mandravelis, V. 2011. The Specifar takeover by the US Watson Pharmaceuticals, http://www.kathimerini.gr/429155/article/oikonomia/epixeirhseis/otan-h-ellhnikhepixeirhsh-specifar-e3agorazetai-apo-thn-amerikanikh-watson-pharmaceuticals (in Greek).

Mukwiri, J. 2008. Implementing the Takeover Directive in the UK. Unpublished PhD Thesis, University of Leicester, UK.

Papageorgiou, G. 2015. The truth about the recapitalization of banks in numbers, http://www.ert.gr/i-alithia-gia-tin-anakefaleopiisi-ton-trapezon-meArithmous (in Greek).

PWC. 2016. Mergers and Acquisitions in Greece during 2015 (in Greek).

PWC. 2015. 2014: Mergers and Acquisitions in Greece (in Greek).

Ruling, S. 2012. In Their Defence: Arguments in the debate over the use of corporate takeover defences and their policy implications. Unpublished PhD Thesis, University of Albany, USA.

Skouzos, I. \& Partners. 2016. Mergers \& Acquisitions (Tax Law), http://www.taxlaw.gr/en/practice-areas/mergers-acquisitions (in Greek).

Staikouras, P.K. 2008. Corporate governance and investor protection in Greece: regulatory and supervisory reform from a law and finance perspective. European Business Organisation Law Review 9(3), 383.

Stavrou, N. 2014. Mergers and Acquisition Approaches. University of Piraeus (in Greek).

Stokka, S.H. 2013. Defence tactics in hostile takeovers: An analysis of the rules imposed on the pursued target. Southampton Student Law Review (3)1.

Tachmatzidi, I., 2016. A comparative study on the role of takeover defences in strong and weak Economies in the European Union: The case of the United Kingdom and Greece. Unpublished LLM Dissertation, King's College London, UK.

Takeovers Panel. 2013. Guidance Note on Defensive Tactics and Target Companies $\left(2^{\text {nd }}\right.$ edn).

Tsibris, M., Koumettis G. 2014. Greece Takeover Guide. Souriadakis \& Tsibris Law Partnership (in Greek). 